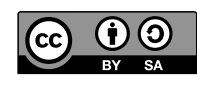

DOI: $10.4312 / \mathrm{mz} \cdot 57.2 .127-153$

UDK 78.07(497.16=163.6)"19":929Pogačar A.:929Matjan V.

\title{
The Contribution of Anton Pogačar and Vida Matjan to the Music Culture of Montenegro
}

\author{
Jelena Martinović Bogojević, Vedrana Marković \\ University of Montenegro, Podgorica
}

\begin{abstract}
The prominent Slovenian musicians Anton Pogačar and Vida Matjan made an exceptional contribution to the development of the music culture of Montenegro in the second half of the twentieth century. The paper aims to highlight the most important segments of their professional activities in this context and present them to the wider musicological public.
\end{abstract}

Keywords: Anton Pogačar, Vida Matjan, state music schools, music culture, Montenegro

\section{IZVLEČEK}

Ugledna slovenska glasbenika Anton Pogačar in Vida Matjan sta zaslužna za izjemen prispevek k razvoju glasbene kulture v Črni gori v 2. polovici 20. stoletja. Članek želi v tem kontekstu osvetliti najbolj pomembna poglavja njune poklicne dejavnosti in jih predstaviti širši muzikološki javnosti.

Ključne besede: Anton Pogačar, Vida Matjan, državne glasbene šole, glasbena kultura, Črna gora 


\section{Introduction}

The music culture of Montenegro began to develop in systematic terms after the Second World War, and this process was helped to a considerable degree by Slovenian musicians Anton Pogačar (1913-1995), and Vida Matjan (18961993). Their arrival in Montenegro was a consequence of a range of differing circumstances. Vida Matjan arrived in Kotor as a mature and experienced musician, following the bombing of Belgrade in 1941, the town in which she had lived with her family for the previous eleven years. ${ }^{1}$ Her role in developing the musical life of Kotor was emancipatory, and she will be most fondly remembered for her works on musical fairy tales. Not long after the end of the war, in 1946, Anton Pogačar arrived in Montenegro, having been sent by the Ministry of Education of the People's Republic of Slovenia, to act as an expert advisor, aiming to help organise and develop public musical education there. ${ }^{2}$ Given the context of his work, both in terms of the times and the cultural environment, Pogačar can be considered the founding father of Montenegrin musical education. Vida Matjan settled in Montenegro for the rest of her life, while Anton Pogačar moved to Pula (in Croatia) in 1963, where he remained until his death in 1995.

The impact and influence of musicians from more advanced regions is a defining feature of the cultural development of Montenegro from as early as the second half of the nineteenth century, and as such the role played by these Slovenian musicians can be seen as a continuation of this tradition into the second half of the twentieth century. ${ }^{3}$ Acting as versatile music pedagogues, conductors and composers, they left an important mark on the musical life of

1 The reason for Vida Matjan to choose Kotor as the place where she and her husband Alojz and daughter Sonja took refuge due to the war was the business contacts that Alojz Matjan, an engineer, had made in Montenegro from as early as 1936, as well as their earlier, occasional stays in this city. The biographical facts related to Vida Matjan are taken from the testimony of Miloš Milošević, her long-time friend and colleague. Miloš Milošević, "Vida Matjan," in Muzičke teme i portreti (Titograd: Crnogorska akademija nauka i umjetnosti, 1983), 125-137.

2 Anton Pogačar, "Iz života i rada Srednje muzičke škole Njegoš," in Deset godina Srednje muzičke škole Njegoš Cetinje - Kotor 1946/47-1956/57: Almanah, ed. Pero Šegota (Kotor: Srednja muzička škola, 1957), 59-99.

3 The most prominent foreign musicians who were active in the musical life of Montenegro as performers, music educators and composers were: Anton Schultz, Franjo Wimmer and Robert Tollinger. A special mark on the musical life of Kotor was left by the Italian composer Dionisio de Sarno San-Giorgio (1856-1937). During his stay in Kotor (1886-1892), de Sarno took part in the launch of the first music school, within the Građanska muzika (Civic Music), orchestra he led at the time. Miloš Milošević, "Dionizije de Sarno San Đorđo," in Muzičke teme i portreti (Titograd: Crnogorska akademija nauka i umjetnosti, 1983), 83-117. Special attention was paid to music education at the Girls' Institute (1869/76; 1878/1913), which was founded in Cetinje under the auspices of the Russian Empress Maria Alexandrovna. Classes were conducted according to the curricula that were in use in educational institutions of this type in Russia. 112 girls, including Slovenian women, were educated at this institution. Music was also taught as an integral part of the program in gymnasiums and Bogoslovia (1869), the orthodox school in Cetinje. Jelena Martinović Bogojević, "Views of Elementary Music Education in Montenegro and Slovenia," Javno glasbeno solstvo na Slovenskem: Pogledi ob 200-letnici-Glasbenopedagoški zbornik Akademije za glasbo v Ljubljani, 25, thematic issue (2016): 306. 
two cultures, Slovenian and Montenegrin. Today, their work and influence are insufficiently examined and remain unknown to the wider music audience.

In order to gain new insights, alongside consulting the scarce literature and partially preserved archival material, ${ }^{4}$ a series of interviews were conducted with their former students and associates, and the methodology of combining public and private data was used.

\section{The Establishment of the System of State Music Schools in Montenegro}

In the years between the two world wars, the musical life in Montenegro rested on music societies, city orchestras, and the activities of individual musicians. The first initiative to establish a music school within Pjevačko društvo Njegoš (Njegoš Singing Society, 1871-1940) in Cetinje was launched by the composer and conductor Jovan Milošević, ${ }^{5}$ who returned to Montenegro in 1922 . The school started operating in $1932 .{ }^{6}$ In terms of the organisation of the work of the school and the teaching process, he was helped in no small measure by a Czech musician, the pianist Bohuslav Šula, and the Croatian composer Milo Cipra who wrote his orchestral work, Sinfonietta, during this period (1934). ${ }^{7}$

Immediately after the First World War, Pjevačko društvo Branko (Branko Singing Society) was formed in Podgorica, led by Aleksa Ivanović. ${ }^{8}$ In 1931, he formed a chamber orchestra, which originated from the Vojni muzički orkestar (Army Music Orchestra) (1907), led by the Czech musician Karl

4 This especially refers to Anton Pogačar, while the opus of Vida Matjan is preserved as her legacy in the Historical Archive in Kotor.

5 Jovan Milošević (1895-1959) was a Montenegrin composer and conductor who completed his studies in 1922 at the Prague Conservatory. After returning to Cetinje, he was a music teacher at the Cetinje Gymnasium and the choirmaster of the Njegoš Singing Society up to 1926 . He was also engaged in collecting Montenegrin folk songs and arranging them for choral performance. Vukašin Vlahović, "Presjek razvoja muzičkog stvaralaštva Crne Gore," in Udruženje kompozitora Crne Gore: 25 godina, ed. Marko Rogošić (Podgorica: Udruženje kompozitora Crne Gore, Kulturno-prosvjetna zajednica Podgorica, 1996), 27.

6 Manja Radulović Vulić, "Muzička kultura u Crnoj Gori," in Crna Gora, eds. Olga Perović, Sreten Perović, Stanislav Vujošević, and Čedo Vuković (Titograd: Organizacioni odbor dana Crne Gore, 1981), accessed February 15, 2021, http://www.montenegrina.net/pages/pages1/muzika/ muzicka_kultura_u_cg_m_radulovic_vulic.htm.

7 Vlahović, "Presjek razvoja," 27.

8 Aleksa Ivanović (1888-1940) was a music pedagogue, composer, and conductor. After acquiring music education within the Orkestar Druge vojne muzike (Orchestra of the Second Military Music) in Cetinje he graduated from the Prague Conservatory in 1911. Upon his return to Montenegro, he was a music teacher at the Gymnasium in Cetinje, and a choirmaster and chaplain of the tamburitza section of the Workers' Society. He led the Njegoš Singing Society, and after the first world war (from 1922) he led the singing societies named Branko, Njegoš, Naprednik and Gajret in Podgorica. He is credited with the development of music education and music culture in Montenegro in the inter-war period. According to Milica Gajić, "Aleksa Ivanović," in Srpski biografski rečnik, IV: I-Ka, ed. Čedomir Popov (Novi Sad: Matica srpska, 2009), also valuable is the website http://montenegrina.net/fokus/milica-gajic-biografije-ivanisevic-jovana-ivanovicalekse-i-jovovic-spiridona-spira/, accessed February 17, 2021. 
Herring. ${ }^{9}$ Ivanović must be viewed as one of the most important creators of the musical life of Montenegro. His dynamic activities included the founding of Muzička škola Branko (Branko Music School) in 1937, which operated until $1940 .{ }^{10}$ In the Bay of Kotor, under the influence of Austro-Hungarian culture, ${ }^{11}$ there were numerous artistic and cultural societies. ${ }^{12}$ Within these societies, informal musical education was provided to the local population by certain musicians with an inclination for music teaching.

In the decade after the Second World War, the development of music education was marked by the creation of a common system of music education across the former Yugoslavia. It was necessary, due to the varying characteristics and circumstances of music education in the individual Yugoslav republics, to form a certain type of consensus, which was characterised by the creation of an umbrella document called "Bledski dogovor" (the Bled Agreement, 1949). It defined the state concept of music education, which consisted of the vertical of the lower (i.e., primary), secondary and higher educational levels. The status of music schools was regulated by regulations in each republic, which were harmonised at the state level, and which determined the function and duration of music education, as well as the expected competencies of students after their graduation. ${ }^{13}$

One of the basic strategies of the Montenegrin educational policies was the establishment of state music schools. Based on the decision of the Ministry of Education of the Federal Republic of Montenegro from November 1946, the

9 Vesna Ivanović, “O prošlosti/About the Past," in Montenegrin Symphony Orchestra: The first decade 2007-2017, eds. Žarko Mirković and Jelena Jovanović-Nikolić (Podgorica: Muzički centar Crne Gore, 2017), 51-53.

10 Cvjetko Ivanović, "Muzika u Crnoj Gori nekad i sad," in Udruženje kompozitora Crne Gore: 25 godina, ed. Marko Rogošić (Podgorica: Udruženje kompozitora Crne Gore, Kulturno-prosvjetna zajednica Podgorica, 1996), 11-29.

11 The Bay of Kotor was controlled by the Austro-Hungarian Empire from 1814 to 1918.

12 Gradska muzika (City Music, 1886) in Herceg Novi, Građanska muzika (Civic Music, 1925) in Tivat, and in Kotor Gradska muzika (City Music, 1842), and Srpsko pjevačko društvo Jedinstvo (Unity Serbian Singing Society, 1839).

13 The system of lower (primary) music schools was designed so that they were not compulsory, and students attended them in parallel with compulsory primary school. The curriculum consists of musical subjects (i.e., instrument, solfeggio, choir singing). High schools of music were specialised schools that students enrolled in, preparing them for professional music practice. Studies at the high music school lasted for four years, and the curriculum consisted of specialised music and general education subjects. After graduating from high music school, students continued their higher education at the university level (i.e., at various music academies). The system of public music education was free of charge, which was one of the democratic values of the educational policies of the Socialist Federal Republic of Yugoslavia (SFRY). The system has retained its basic characteristics to this day in the countries of the former Yugoslavia. More about the system of music education in the SFRY can be found in Branko Rakijaš, "Muzičko školstvo u Jugoslaviji," in Muzička enciklopedija, II, ed. Krešimir Kovačević (Zagreb: Jugoslovenski leksikografski zavod, 1974), 654 . 
first state music school, named Državna muzička škola Njegoš ${ }^{14}$ was founded. It was located in the Biljarda ${ }^{15}$ building in Cetinje until 1951. The school started working as a primary level music school in January 1947, and from the school year 1948/49 it grew into a music boarding school at secondary level. The first Principal of the school was Anton Pogačar, who remained in that position until his retirement in 1963. In 1951, the authorities decided to temporarily move the school to Kotor, where it operated for the next seven years, after which it was moved to Titograd (now Podgorica) as the capital of the Republic of Montenegro. ${ }^{16}$

Immediately after the war, in 1945, Vida Matjan, as a piano teacher, founded her private music school in Kotor. With the consent of the state authorities, this school operated until 1 April 1947, when it merged with the newly established Državna škola za osnovno muzičko obrazovanje (State School for Primary Music Education) in Kotor. Officially, from 1949, Vida Matjan became the Principal, and remained in that position for the next twenty years, until her retirement in $1969 .{ }^{17}$

In addition to Cetinje and Kotor, during the first post-war years, primary level music schools were established in other Montenegrin cities: in Nikšić (1948), Pljevlja (1948), Ivangrad (now Berane; 1949), and Herceg Novi

14 The school was named after Petar II Petrović Njegoš (1813-1851), the Prince-Bishop of Montenegro and a Montenegrin poet and philosopher.

15 Biljarda (Billiard House) is the name of the former residence of Petar II Petrović Njegoš. It is located in the city centre of Cetinje and dates from 1838. It was named after the billiard table that Njegoš brought from Vienna, which at that time was the first and only billiard table in Montenegro.

16 Decision of the Executive Committee of the Federal Republic of Montenegro of March 21, 1958 (Podgorica, Arhiv Umjetničke škole za muziku i balet).

17 At the beginning of the 1950s, after completing his studies at the Academy of Music in Belgrade, another Slovenian musician, Rudolf Zakrajšek moved to Kotor. Rudolf (Rudy) Zakrajšek (1915-1994) was born on 25 February 1915 in Trebnje (in Slovenia). He graduated from the Academy of Music in Belgrade in composition, conducting, and double bass playing. After moving the school from Kotor to Titograd, Rudolf Zakrajšek would work as a teacher, and then as the long-term principal of the Vasa Pavić State Primary Music School. During his mandate, in 1972, a ballet school was also founded. After 1980, Rudolf Zakrajšek taught the subject Methodology of the Teaching General Music Education at the newly established Academy of Music (1980) for eight years. He was the co-author of a textbook package for music education for the third and fourth grades of primary school titled Muzičke radosti (Musical Joys, 1983). He was an active member of the Association of Music Artists of Montenegro and one of the founders of the Association of Composers of Montenegro, of which he was president twice, from 1981 to 1982, and from 1984 to 1986. He was also active as a conductor of the Symphony Orchestra of the Radio Television of Montenegro. As a composer he wrote Piano Miniatures, Theme with Variations for Violin and Piano, and further orchestral works Paraphrases and Orchestral Meditations. Rudolf Zakrajšek was awarded the Lifetime Achievement Award by the Association of Composers of Montenegro in 1981. He died in Podgorica on 12 December 1994. The biographical facts are taken from Manja Radulović Vulić, "In Memoriam: Rudolf Zakrajšek: Crnogorski Slovenac," Pobjeda (private archive of his grandson Zoran Zakrajšek, accessed March 1, 2021). 
(1949). ${ }^{18}$ From then on, music education continued to develop, and future teaching staff began to be educated at the Academy of Music ${ }^{19}$ which was founded in 1980 as one of the nineteen university units at Univerzitet Veljko Vlahović (Veljko Vlahović University) ${ }^{20}$ in Titograd (now Podgorica). Thus, Montenegro was the last of the Yugoslav republics to establish a tertiary level institution for music education. ${ }^{21}$

\section{Anton Pogačar - The Visionary Founder of Music Education in Montenegro}

The significance of Anton Pogačar for music education in Montenegro can be compared with the significance that the Slovenian composer Davorin Jenko (1835-1914) had in terms of the development of music life in Serbia in the second half of the nineteenth century. Anton Pogačar came to Montenegro as an educated musician, having first been educated at the Vojna muzička škola (Military Music School) in Vršac (1920-1941), after which he worked as a military musician in Ljubljana. He would continue his education at the Ljubljana State Conservatory (1926-1939) where he completed his studies in the class of the composer Slavko Osterc (1895-1941). Before coming to Montenegro, he worked as a teacher in the music school in his native town Celje. ${ }^{22}$

Upon his arrival in Cetinje, Pogačar, in addition to the position of the principal of the Njegoš State Music School taught theoretical music subjects and the violin.Pogačar's wife Zdenka (Leskovec) Pogačar was a piano teacher. The school began operating on 1 January 1947, and the teaching staff was mostly composed of foreign musicians (Spaček, Santamario, Mazzoleni, Bohuslav Šula). ${ }^{23}$

The founding of the school attracted significant interest from among the local population, far surpassing the original expectations of the founders (as many

18 Today, there are fourteen music schools in Montenegro, of which thirteen are state run, and one is a private-state school. Five schools in Montenegro operate as schools for primary and secondary music education. "Muzičke škole," in Školska mreža, accessed May 14, 2021, http://www.skolskamreza.edu.me/muzicke-skole/.

19 After a fire at its temporary home in February, in which a great number of instruments and documents were lost, the Academy of Music was moved to Cetinje (old royal capital of Montenegro) in October 1996, in the building of the former British Embassy, where it is still located today.

20 The University was founded under this name in 1974. In 1992 it became the University of Montenegro.

21 For more on the development of the Academy of Music, see Sonja Marinković, "Muzička akademija na Cetinju: Pogled na osnivanje, razvoj i sadašnji rad najviše obrazovne institucije u Crnoj Gori," in Muzičko školstvo u Crnoj Gori - dometi i perspektive, 144, no. 43, ed. Žarko Mirković (Podgorica: CANU, 2018), 83-94.

22 Vukašin Vlahović, “Anton Pogačar," Muzički glasnik, no. 4 (1988): 30-31, accessed February 20, 2021, http://www.montenegrina.net/pages/pages1/muzika/anton_pogacar.htm.

23 From the archive of the Vasa Pavić Art School for Music and Ballet in Podgorica. 
as 746 candidates applied to study at the school, of which 156 were enrolled). ${ }^{24}$ The great enthusiasm for musical education on the part of the staff is demonstrated by the number of public performances by the pupils of the school in its first year of operation. However, the development of the school to include secondary music teaching, in the 1948/49 school year, caused various issues. Pogačar stated that, due to the lack of interest among pupils in professional music training, it became necessary to go from house to house, assessing the musical talent of potential pupils and persuading the parents to send them to the boarding school in Cetinje, in order to train them as professional musicians. There were also a number of war orphans among the intake of pupils, whose musical talents had been recognised by the teaching staff. In total, the first intake of the secondary school numbered fourty-nine students. Under the direction of Pogačar, from the second year of its existence, the school had gained a widespread reputation, with the pupils and teachers performing a series of concerts, including an openair concert and performance for the workers who built the Omladinska pruga Nikšić-Titograd (Nikšić-Titograd Youth Railway). The concert tour of Albania in April 1948, with performances in Shkodra and Tirana, is also particularly noteworthy, not least for its success among the local audience.

Despite the relative lack of qualified teachers, the school offered the full range of specialisations, including solo-singing which was taught by Kornelija Ninković-Grozano (1897-1986), the former prima donna of Beogradska opera (Belgrade Opera House). The school also took on responsibility for courses for music teachers at primary school level, so as to improve the generally poor quality of music teaching, through the elementary development of basic professional competencies.

The school attracted particular attention and affirmed the relevance and quality of their work through their involvement in the jubilee celebrations of the centenary of the death of Petar II Petrović Njegoš, which took place in 1951. Anton Pogačar was on the Organising Committee of this event. The work of the school was highly rated by evaluators sent from Belgrade, among whose number we find such eminent figures as the composer and conductor Oskar Danon (1913-2009) and the Serbian composer Petar Konjović (1883-1970). However, the school suffered from a lack of support and understanding on the part of the government, which would not provide increased financial support for the development of better material conditions at the school, and this led to a reduction in the already limited number of qualified teachers. ${ }^{25}$

Due to poor conditions in the Biljarda building in Cetinje, the government ordered that the school be moved to Kotor temporarily in 1951 . One

24 A timeline of the development of the school is presented in Pogačar, "Iz života i rada," 59-99.

25 For instance, the cellist Camilo Mazzoleni was offered a position at the Ljubljana Philharmonic and left the school in 1950. With the moving of the school to Kotor, the composer Jovan Milošević, who was head of the woodwind section of the school, decided to leave for personal reasons. Ibid., 70. 
positive consequence of this was that the school, together with Kulturnoumjetničko društvo Nikola Đurković (Nikola Đurković Cultural and Artistic Society), founded the Symphony Orchestra (1953/54) led by composer Ilija Lakešić. After the orchestra ceased operating in 1956, the school founded its own orchestra whose public performances made a substantial impact on musical life in the Bay of Kotor, until the school moved to Titograd in 1958. ${ }^{26}$ Young Slovenian musician Rudolf Zakrajšek, who had originally trained as a double bassist and conductor, acted as conductor for a number of the concerts, while Pogačar led the mixed choir of the music school, which quickly gained a significant reputation. At this time, Vida Matjan was the principal of the State School for Primary Music Education in Kotor, and was actively engaged in organising its musical activities, including arranging public performances of her musical fairy tales by the students of the school.

The pedagogical mission of Anton Pogačar can be considered a success from the very start, thanks to the first class of students who completed their secondary music education, and among whom there were future prominent musicians who continued their education at various music centres across the former Yugoslavia. ${ }^{27}$

26 The continuity of the Njegoš State High Music School endured after moving to Titograd, where, in 1978, the school was integrated into the Vasa Pavić School of Primary Music Education, which at that time was headed by Rudolf Zakrajšek, forming a new primary and secondary music education institution under the umbrella name Centar za muziku i balet Vasa Pavić (Vasa Pavić Centre for Music and Ballet). Since 2005, the school has been called Umjetnička škola za muziku i balet Vasa Pavić (Vasa Pavić Art School for Music and Ballet). "70 godina škole: Koncert 'Susret Generacija' povodom jubileja škole: Program," in J. U. umjetnička škola za muziku i balet 'VASA PAVIĆ' (June 5, 2017), accessed May 18, 2021, http://kicpodgorica.me/wp-content/uploads/2017/06/ program-Koncert-Susret-generacija-5.pdf.

27 Among the first students to complete their studies, we find the following musicians: Tripo Simonuti (violin), Mirko Bratičević (piano), Boro Tamindžić (composer), Cvjetko Ivanović (conductor), Konstantin Ivanović (double bass), Svetozar Purko Aleksić (clarinet), and Julio Marić (conductor). Musicians from Montenegro mostly continued their education at the Music Academy in Belgrade, as the capital of Yugoslavia, while there were also those who completed their studies at the music academies of Sarajevo and Zagreb. A smaller number of students went to Ljubljana, presumably because of the language barrier. 


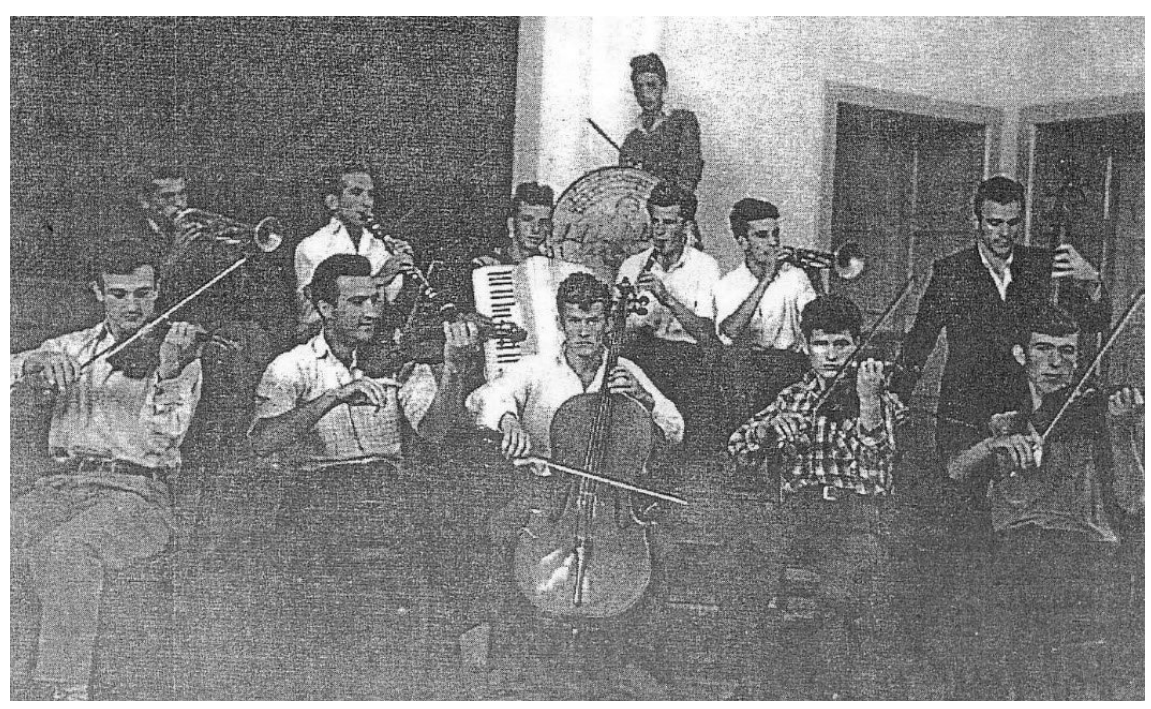

Figure 1: The students of the first graduating class of the Njegoš High School of Music in $1950 .^{28}$

In order to complete out impression of Anton Pogačar, both as a teacher and a personality, we should consider the evidence offered by his former pupils. According to the recollections of Julio Marić, ${ }^{29}$ Pogačar was a born teacher, who often personally financed the students' food and helped poor students and their families. Marić remembers him as someone who was adept at equipping the school with materials and instruments that were difficult to find at the time. Marić offers the following account of Pogačar's personality and approach in recalling his own first days as a pupil at the school in Cetinje:

One day at 9 o'clock in the morning they tested my musical abilities, and already at 11 o'clock they took me to Cetinje. I was 13 then. I wanted to play the piano, but due to my extraordinary pitch ear, Pogačar insisted that I start learning the violin. Dissatisfied, after fifteen days I ran home from Cetinje,

28 Accessed March 3, 2021, http://www.cetinje-mojgrad.org/2010/08/srednja-muzicka-skola-nacetinju-konstantin-ivanovic/.

29 Julio Marić, a conductor, composer, and university professor was born in 1937 in Dubrovnik. He completed his studies at the Njegoš State High Music School in Kotor in 1956. He then studied conducting and composition at the Academy of Music in Sarajevo, also in 1956, and graduated with a master's degree two years later. Subsequently, he taught at the Academy of Music in Sarajevo, and during the 1990s was a professor at the Academy of Music of the University of Montenegro. "Bivši učenici: Julio Marić," in Škola za osnovno muzičko obrazovanje Herceg Novi (2015), accessed May 12, 2021, http://muzickahercegnovi.com/page/12/. Julio Marić shared his memories of Anton Pogačar: Julio Marić, personal conversation with authors, February 14, 2021. 
in a truck. However, during the day, the police came to look for me and they made me return to the music school in Cetinje. The same thing happened again after about ten days, I ran away again, but this time, when I got home, Pogacar and the police were already waiting for me, and they sent me back to school. This time the Principal relented and allowed me to study both piano and violin. When I went to Novi Sad to further my education, Pogacar lent me his violin, which I later returned to him. ${ }^{30}$

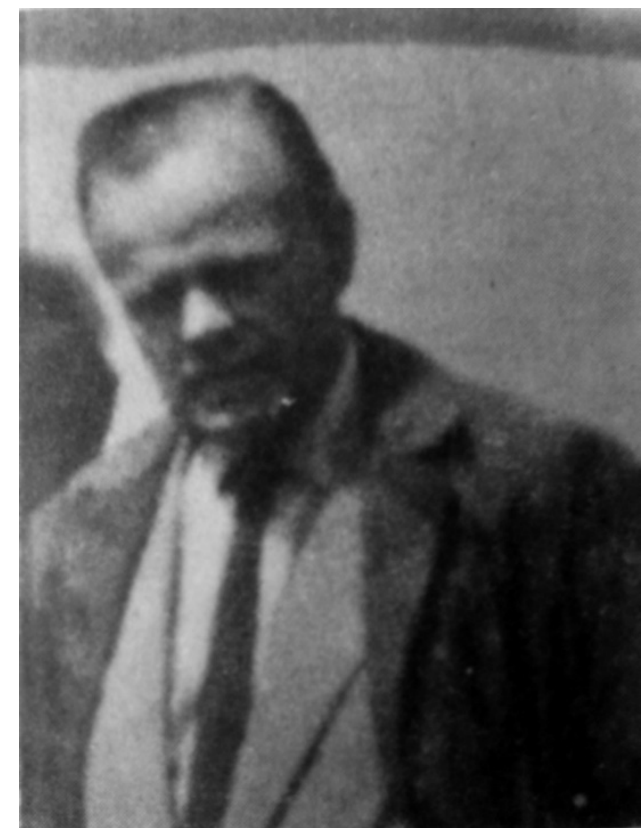

Figure 2: Anton Pogačar. ${ }^{31}$

Among the first students to complete their studies at the secondary school, we find the renowned Yugoslav violinist Tripo Simonuti, who was quick to credit Anton Pogačar with a key role in encouraging him to take up music professionally, recalling the advice he received to continue studying music in Belgrade. Simonuti's memory of his departure from the school is particularly vivid, with Pogačar giving him the violin he later used, and one of the two suits he owned, in order that he could be dressed appropriately for the journey to Belgrade. This memory on the part of Tripo Simonuti shows us the almost parental sensibility that Pogačar felt towards the students he had taught at

30 Marić, personal conversation.

31 Rogošić, Udruženje kompozitora Crne Gore, 31. 
the boarding school, since they often came from poor families. In particular, Simonuti highlighted the quality of the competencies he acquired as a result of Pogačar and his teaching, which meant that adjusting to the high standards expected of him in his new learning environment posed no real difficulty. ${ }^{32}$

In addition to initiating music pedagogy, Anton Pogačar recognised certain specific Montenegrin cultural and musical needs, and thus he worked diligently as an organiser of musical life, and was actively involved in the establishment of the first music associations, most notably as the president of the management board of Asocijacija produktivnih i reproduktivnih umjetnika Crne Gore (Association of Productive and Reproductive Musicians of Montenegro, 1949), and as the secretary of Udruženje muzičara Crne Gore - UMCG (Association of Musicians of Montenegro, 1955)..$^{33}$

In order to support the further development of music teaching, Pogačar published a manual Muzički priručnik za nastavu pjevanja u srednjim školama (Music Manual for Teaching Singing in High Schools; 1948) with illustrations provided by the Slovenian artist Lojze Perko (1909-1980). ${ }^{34}$ The manual covered basic musical theory, elementary explanations of the anatomy of the vocal apparatus, and also a section featuring a selection of choral compositions, which were specially adapted to the repertoire of school choirs. This was the first organised manual for music teachers to be published in Montenegro. As one of the key figures in the organisations of musical life of the time, Pogačar published number of articles in which he analysed and highlighted certain specific features, critically engaging with the development of future strategies for the development of music teaching in Montenegro. ${ }^{35}$

\section{Traces of the Musical Works of Anton Pogačar}

We lack sufficient information on the compositions of Anton Pogačar. Before coming to Montenegro, he had published two collections in Slovenia. Their titles suggest that they consisted mainly of musical arrangements. The first one was a collection of 100 practice pieces for the accordion, based on folk songs and partisan songs from the Second World War (Pionir na harmoniko: 100 vaj

32 Tripo Simonuti,"Spavao sam sa violinom," interview by Slavko Trošelj, Politika, April 22, 2007, accessed February 25, 2021, http://www.politika.rs/sr/clanak/1966/.

33 Marko Rogošić, "Osnivanje prvih muzičkih udruženja u Crnoj Gori 1947-1957," in Udruženje kompozitora Crne Gore: 25 godina, ed. Marko Rogošić (Podgorica: Udruženje kompozitora Crne Gore, Kulturno-prosvjetna zajednica Podgorica, 1996), 30-33.

34 Anton Pogačar, Muzički priručnik za nastavu pjevanja u srednjim školama (Cetinje: Narodna knjiga, 1948).

35 Information on these activities is held in the digital database of the Đurđe Crnojević National Library of Montenegro in Cetinje. The articles were published in the magazines Ovdje, Prosvjetni $\mathrm{rad}$, and in the newspaper Pobjeda. 
za zacetnike, 1946). ${ }^{36}$ The other one was a collection of melodies from the operetta Porodni moz (The Water Man), based on the ballad of the same name by the most significant Slovenian nineteenth-century poet France Prešeren (18001849). ${ }^{37}$ Pogačar composed the operetta before arriving in Montenegro (1946). His known works also include the musical score for a play, based on the traditional fairy tale Čardak ni na nebu, ni na zemlji (A Tower neither in Heaven nor on Earth), which was performed at Narodno pozorište u Kotoru (National Theatre in Kotor). ${ }^{38}$ In Montenegro, he published seven works with the publisher Narodna knjiga in Cetinje between 1946 and 1950. However, number of significant works, including the cantata Spomenik (The Monument), for which he received an award in 1960, have never been published, and the manuscripts of these works have not yet been discovered in the available archives in Montenegro.

Pogačar's clear interest in the specific nature of the Montenegrin folklore led initially to the creation of the first series of harmonized treatments of folk songs for choirs, and then appeared later in new creative works, into which the original folkloric melody tradition was incorporated in a holistic and authentic manner. Notable examples of choral compositions which show these features include Sa Lovicena vila klice (The Maiden Sings out from Lovíen), arranged for women's and children's choir, Durmitor and Poljem se vije (Fluttering in the Field). ${ }^{39}$ Pogačar uses the original folk melody, achieving expressiveness through occasional chromatic movements and rich harmonisation. In the collection Zvuci iz Crne Gore (Sounds from Montenegro), Pogačar collected four songs for children's and four for mixed choir, among which we find arrangements of the folk songs Crnogorski biseri (Montenegrin Pearls), Ponosita lovcénska planino (Proud Mount Lovćen) and a song he composed based on Njegoš's verses Bješe oblak sunce uhvatio (There was a Cloud that Caught the Sun). It is thought that these choral compositions were specifically written for the school choir he conducted and intended as part of the music programme which marked the centenary of Njegošs death which was held in 1951. Of Pogačar's instrumental compositions, the miniature Romansa (1949), written for cello and piano, is also preserved in National Library of Montenegro.

36 Anton Pogačar, Pionir na harmoniko: 100 vaj za začetnike; Narodne in partizanske pesmi za klavirsko harmoniko ([S. 1.]: [s.n.], 1946).

37 Anton Pogačar, Venček melodij (Ouvertura): Iz operete "Povodni mož" po istoimenski Prešernovi baladi; Priredba za klavir ([S. 1.]: [s. n.], 1946).

38 Pogačar, "Iz života i rada," 60.

39 In the "Đurđe Crnojević" National Library of Montenegro in Cetinje, the following works by Anton Pogačar are preserved: Pjesme za pionire: Zbirka dječijih horova (1950); Motiv iz Crne Gore (1949); Romansa za violončelo i klavir (1949); Zvuci iz Crne Gore: Crnogorskoj omladini; Dječiji i mješoviti horovi (1947); Muzički priručnik: Za nastavu pjevanja u srednjim muzičkim školama (1948); Pjesma omladinskoj pruzi Nikšić - Titograd [s. d.]; Pjesma graditelizima pruge Titograd - Nikšić [s. d.]. The works are classified in the COBISS database, accessed March 3, 2021, https://plus.cg.cobiss.net/ opac7/bib/search?q=anton+poga\% $\mathrm{C} 4 \% 8 \mathrm{Dar} \& \mathrm{db}=$ cobib\&mat=allmaterials\&start=0. 
Pogačar wrote music for the theatre play Gorski vijenac (The Mountain Wreath) based on the poem by Petar II Petrović Njegoš, which was performed in 1960 at the Titograd National Theatre. The play, adapted and directed by the Montenegrin theatre director Nikola Vavić (1924-2019), was also premiered in Zagreb, on the occasion of the centenary of Hrvatsko narodno kazalište (Croatian National Theatre) on 11 December 1960. In this play, music acted as a striking constructive element, so that we might define the work as a kind of combined musical-dramatic presentation, which featured numerous choral recitals, as was suggested by the review of the premiere which appeared in the Zagreb newspaper Vjesnik..$^{40}$

Pogačar's particular feeling for Montenegrin folk elements is also evident in his miniature for violin and piano Motiv iz Crne Gore (Motiffrom Montenegro, 1949), which in a descending melody contains certain characteristic intervals of the major and minor seconds.

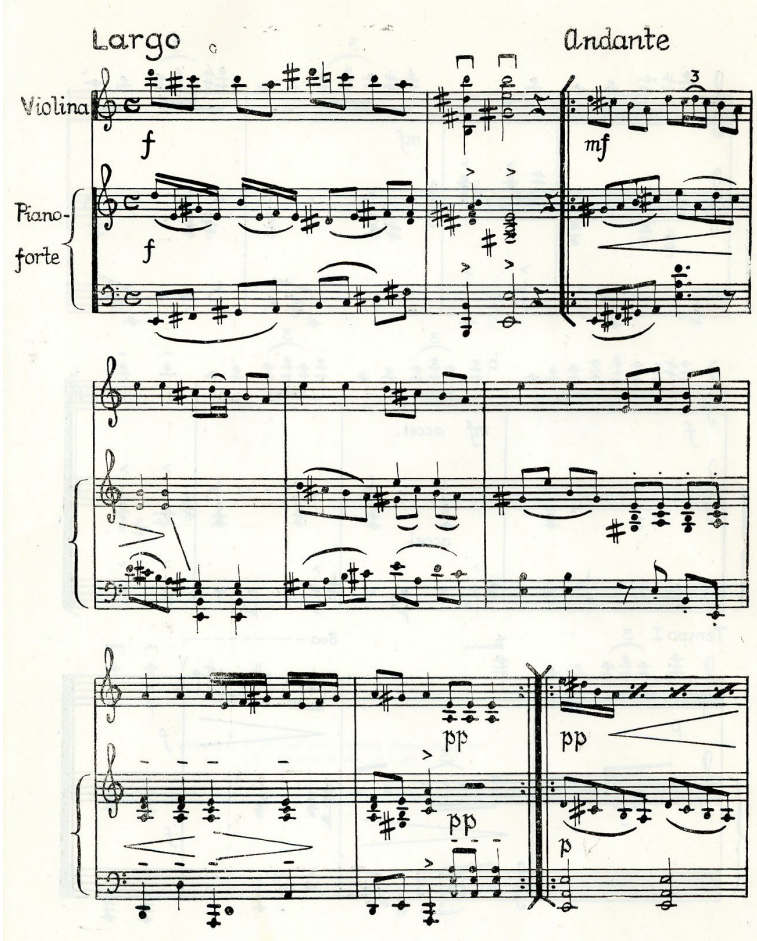

Figure 3: Initial bars of the composition Motiffrom Montenegro. ${ }^{41}$

40 Milovan Radojević, "Prve dvije decenije Crnogorskog narodnog pozorišta," Matica (2013), 364.

41 Anton Pogačar, Motiv iz Crne Gore (Cetinje: Narodna knjiga, 1949), 2. 
Pogačar generally wrote choral compositions with themes that were typical of the period after the Second World War, including ideas of struggle and renewal, but also created pioneer songs written for children's choir. ${ }^{42}$

For his entire work in the field of music culture, as well as for the cantata The Monument ${ }^{43}$ Anton Pogačar received the highest Montenegrin recognition, Trinaestojulska nagrada (Thirteenth of July Award). After retiring, he left Montenegro in 1963 and settled in Pula, where he died on 23 November $1995 .{ }^{44}$ The position of principal of the High School of Music in Titograd was subsequently held for many years by people who were not musicians, which also influenced the lack of a strategy for educating future instrumentalists, a situation which continued until the 1980s.

\section{Vida Matjan - Remarkable Currents in Music Pedagogy}

Vida Matjan has a special role in the development of music culture in Montenegro, as a person of broad culture, who turned her multiple artistic talents to music pedagogy. The city of Kotor, which has a long musical tradition and rich cultural heritage, was an open and stimulating environment in which Vida Matjan realised her creative musical ideas.

Vida Matjan ${ }^{45}$ (née Hribar) was born on 6 May 1896, in Ljubljana into a family that belonged to the ranks of civil society. She gained her first musical knowledge from her mother Antonija (née Učak), a dramatic soprano, who acquired her music education at Glasbena matica, where she was taught by Fran Gerbič (1840-1917). Her father did not agree with her desire to become a musician. However, after finishing the third grade of high school with great success, he approved her enrolment at Glasbena matica in 1911, where she was taught piano by Anton Trost (1889-1973). After receiving a scholarship, she enrolled in piano studies in Vienna, but her studies were interrupted by the First World War, and the death of her mother in 1913, and she returned to Ljubljana. ${ }^{46}$ In 1917, she married Alojz Matjan, who was a student of

42 Pogačar's adaptation of the song Teče Tara (1948) for mixed choir belongs to partisan songs from Montenegro, which is still performed today.

43 The score has not been found in Montenegro.

44 The data was obtained from the Registry Office of the City of Pula, February 22, 2021.

45 Biographical data of Vida Matjan are cited from Miloš Milošević, her long-time friend and colleague. Milošević, “Vida Matjan,”125-137.

46 Biographical data of Vida Matjan has been presented to the Slovenian audience in the following articles: Ervina Dabižinović, "Vida Matjan - 'duša svega', uspješna Slovenka u Crnoj Gori," Slovenika: Ćasopis za kulturu, nauku i obrazovanje 4 (2018): 53-80, https://doi.org/10.18485/slovenika.2018.4.1.2; Vedrana Marković, "Influence of Slovenian Culture and Music Pedagogy on the Development of Music Education in Montenegro through Work of Vida Matjan," Mostovi med formalnim in neformalnim glasbenim izobraževanjem - Glasbenopedagoški zbornik Akademije za glasbo v Ljubljani, 31, thematic issue (2019): 161-167; Martinović Bogojević, "Views of Elementary," 307; Ivana Miladinović Prica, "Skladateljice v Črni gori: Zgodovina nekega razmerja," 
technical studies, but also a good organist, pianist, and amateur painter. Vida Matjan made her earliest contact with dramatic art by playing in performances organized by the Slovenian writer Marija Kmet (1891-1974). Thus, she became acquainted with dramatic expression, which she would later apply in her multimodal approach to music pedagogy.

In 1930, she began a higher piano degree ${ }^{47}$ at Srednja muzička škola Stanković (Stanković High School of Music) in Belgrade, being taught by the eminent Czech pianist and professor Emil Hayek (1886-1974). ${ }^{48}$ At that time, she taught a large number of private piano lessons, especially to Slovenes who lived in Belgrade. She also developed her skills in painting on silk, wood, porcelain, and clay, which she perfected with the academic painter and violinist Saša Šantel (1883-1945). She would demonstrate this gift most especially when creating costumes for opera performances commissioned by opera houses in Belgrade, Ljubljana, and Zagreb, and also very clearly in the preparation of the stage performances of her musical fairy tales for which she created and prepared the costumes. ${ }^{49}$ She arrived in Montenegro at the start of the war in 1941, after her house had been destroyed in the bombing of Belgrade.

After the war years, she began to educate children at her Privatna muzička škola Vida Matjan (Vida Matjan Private Music School), which merged, two years later (1947), with the newly established State School for Primary $\mathrm{Mu}^{-}$ sic Education in Kotor, which she ran for the next twenty years. In addition to piano lessons, at the elementary music school as well as at the Njegoš High School of Music, she taught solfeggio to the lower grades. From 1946, she organised and conducted the choir of the Women's Antifascist Front (which had thirty-two members), subsequently leading the Pioneer Choir of 105 members, and various folklore and drama groups. Her work with the school choir was also significant, and with her as conductor they won first prize in certain national competitions. Her ongoing interest in the folklore of Boka Bay was

in Ženskost v glasbi skladateljic po 1918: Pogledi nekaterih manjših glasbenih kultur Evrope, eds. Leon Stefanija and Katarina Bogunović Hočevar (Ljubljana: Oddelek za muzikologijo Filozofske fakultete Univerze v Ljubljani, 2018), 73-90, https://doi.org/10.4312/9789610601388; Katarina Zadnik, "Primary Music School Education in Slovenia and Montenegro," Muzikološki zbornik 55, no. 1 (2019): 195-210, https://doi.org/10.4312/mz.55.1.195-210.

This degree was equivalent to the final year of study at the later Academy of Music in Belgrade.

48 Emil Hayek (1886-1974) was a Yugoslav pianist and piano teacher of Czech origin. He also studied composition with Antonin Dvořák at the Prague Conservatory. From the founding of the Music Academy in Belgrade in 1937 until 1963, he was a full professor of piano and head of the piano department. He is considered the founder of the Belgrade piano school.

49 According to the testimony of her former student Smilja Đuranović, who took part in performing musical fairy tales, a fashion designer from Kotor Trifona Zanutti and her sister helped to make costumes for Vida Matjan. In those years of poverty, there were no textile materials, so the costumes were imaginatively made of crepe paper. Smilja Đuranović, a retired teacher of French language and literature, shared her memories of Vida Matjan with the authors. Smilja Đuranović, e-mail correspondence with authors, March 1, 2021. 
reflected in the fact she collected authentic folk songs and dances, and that she recorded the customs of the region. This collected material was published in 1984 in the ethnomusicological study Igre i pjesme Dobrote $i$ Škaljara (Dances and Songs of Dobrota and Škaljari), in which she described such things as local wedding customs and the characteristic steps of folk dances, giving a complete picture of the whole cultural and ethnographic context. ${ }^{50}$

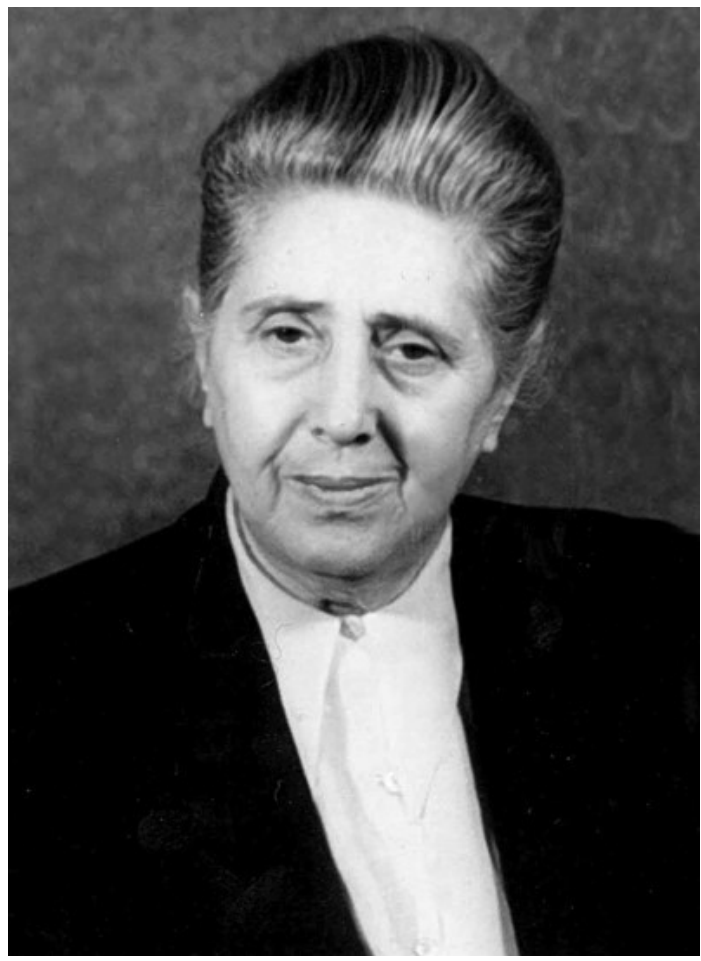

Figure 4: Vida Matjan. ${ }^{51}$

Vida Matjan's vision of music education was not solely tied to piano teaching. The multimodal approach, which is today recognized as an important segment of the interdisciplinary connection of music with other forms of artistic expression, was a basic characteristic of her work with children. We can be certain that this encouraged musical creativity, through a holistic approach which fitted the way in which children learn about the world around them. ${ }^{52}$

50 Out of gratitude, she dedicated this valuable publication to the city of Kotor.

51 Archive of the Vida Matjan Music School.

52 Jackie Wiggins, "Creative Process as Meaningful Music Thinking," in Creativity and Music Education, eds. Timothy Sullivan and Lee Willingham (Toronto, CA: Britannia Printers, 2002), 78-88. 
According to the testimonies of her students, Vida Matjan had an emancipatory role in the life of post-war Kotor. ${ }^{53}$ Her former pupil, the French language teacher Smilja Đuranović, ${ }^{54}$ who enrolled in music school as an eight-yearold girl, played the piano and performed in her musical adaptations for stage performing, described Matjan in the following terms:

Vida Matjan was a very respected, authoritative person who knew how to evaluate the musical qualities of her students. She was not only a piano teacher, but also a pedagogue and a well-educated person who knew how to guide her pupils not only in music, but also in life situations. [...] I remember Ms. Matjan as my music pedagogue, always well-groomed, serious, and demanding when she felt she could reach to higher level. She also held classes on good manners and dress and taught us how to organise our time. When she moved to Kotor with her family, she rented an apartment that included a large room that she used for ballet classes that the children gladly accepted. At the end of the school year, she organised events for students and parents, which were enthusiastically attended. ${ }^{55}$

Vida Matjan showed her professionalism, but also empathy towards her student. Marija Vujović, ${ }^{56}$ a blind music teacher, came to Vida Matjan's piano classes in the late 1950s as a seven-year-old girl. Musically talented children from Dom za slijepe (Home for the Blind) in Risan came to the music school in Kotor with their music teacher, Ivan Odobašić, who was also blind himself. Vida Matjan held piano lessons for these children once a month, gave instructions and systematically supervised their musical development. They received a diploma on completing primary music school, which opened the possibility for these children to continue their music education at the secondary level.

Vida Matjan enjoyed great respect, especially among her colleagues, some of whom were also her former pupils. Marina Dulović, ${ }^{57}$ who talks about her late years and the respect Matjan received from the staff of the music school in Kotor, also testifies to this:

53 Vida Matjan had a large number of pupils, among them later renowned musicians, who always emphasised the valuable experience of working with her. These figures include the conductor Darinka Matić Marović, the conductor Miroslav Homen, the pianist Tamara Jovićević, the conductor and composer Julio Marić, as well as the intellectual, linguist and pastor of the church of St. Eustachia in Dobrota, Don Branko Sbutega (1952-2006).

Đuranović, e-mail correspondence.

55 Ibid.

56 Marija Vujović, in conversation with authors, Cetinje, February 2, 2021 (transcript of the conversation).

57 Marina Dulović, a piano teacher and the long-time director of the Music School in Kotor. Marina Dulović, e-mail correspondence with authors, February 17, 2021. 
Since 1985, every May 6th, on her birthday, the staff of the music school, of which I was a member, went to Mrs. Matjan's house in the Muo neighbourhood of Kotor. The appropriate gift would be given to her by the principal Niksa Cucic, her former student. [...] She approached each of us with devotion and talked about the teaching process, students, class, programmes, methods and problems. She would often play a piano piece that she had rehearsed in those days. [...] The memories remain of a woman who left a deep mark in the field of music culture, working diligently on the tasks of shaping musical life, and of developing and advancing culture and education. ${ }^{58}$

On the occasion of the celebration of the sixtieth anniversary of the founding of the school (2007) it was decided that the school should be named after her. Marina Dulović, as the Principal of the Music School, launched this initiative, which gained widespread support, both among the local population and the music societies of Kotor Bay. Today, the music school in Kotor bears the name School for Primary and Secondary Music Education "Vida Matjan". Since 2009, cooperation has been established with Glasbena šola Franca Šturma (Franz Šturm Music School) in Ljubljana, and until 2015, every May 6th, on the day when Vida Matjan was born, students and professors of the Vida Matjan Music School held notable performances. ${ }^{59}$

\section{Vida Matjan's Musical Opus for Children}

Vida Matjan's compositions for children began with piano and vocal works, notably through musical choreography, and the adaptation of various works of literature for children (being dramatic adaptations accompanied by piano): Slike iz dječijih priča (Images from Children's Stories, 1950), Ježeva kućica (Hedgehog's Cottage, 1951) adapted from the work by Branko Ćopić, and a puppet show based on Ivan Minatti's opus Slamni vočic (The Little Straw Bull, 1955) for which she herself created the puppets. Her approach to writing musical fairy tales evolved from simple piano accompaniment into a rich, child friendly range of performative approaches, incorporating Orff instruments, in combination with strings, woodwind and choirs, solo performance and ballet. In 1963, she created her most famous musical fairy tale Besana šumska noć (The Sleepless Forest Night) based on a lyric by Miloš Milošević, which was performed at the Kongres saveza uruženja muzičkih pedagoga Jugoslavije (Congress of the Union of Music Teachers of Yugoslavia) held on 24 April 1964 in Kotor. Vida Matjan was responsible for the music, the performance direction, and the choreography. 
Further musical fairy tales followed. These included Zamciic Cardačic (The Little Castle, 1966) based on the work by S. Maršak, Klinika Lutaka (The Dolls' Clinic, 1967), which was based on the text by Jovan Aleksić, and Vucko (The Little Wolf, 1968), following the work by Vojmil Labadan. In her later years, showing great vitality and an innovative approach, she wrote an opera for children in four acts, with a libretto by Miloš Milošević, entitled $U$ susret ribama (To Meet the Fish, 1989), which she dedicated to the young people of Kotor. ${ }^{60}$ Her complete musical works included works for the piano and chamber music, vocal and vocal-instrumental pieces and a textbook encompassing teaching methodology, called Muzička početnica (A Music Primer, 1981), which was also written with Miloš Milošević. ${ }^{61}$

If we wish to understand the origin of the very innovative approach to music education which she provided for her pupils, then Vida Matjan offers a clear definition herself:

\begin{abstract}
I paid attention to rhythmic games, small recitations often with musical accompaniment and acting. Through frequent contact with parents and educators and through endless work with the children, I got a clear idea of how to compose for children. This was the beginning of my personal development phase that led me to today's level of dealing with this form of educational work. ${ }^{62}$
\end{abstract}

We cannot speak of Vida Matjan as having a particular musical role model, nor of her as following a pre-existing method of teaching, but rather of her approach to music teaching as emerging very specifically from her deep understanding of the psyche of the child, as well as her instinctive recognition of musical ability and her unerring approach to developing talent.

For the musical fairy tale The Sleepless Forest Night, ${ }^{63}$ together with the author of the lyrics, Miloš Milošević, she received the highest Montenegrin award, the Thirteenth of July Award in 1965. Among other numerous awards she received, we find Zlatna medalja Saveza kompozitora Jugoslavije (Gold Medal of the Yugoslav Composers' Association), which was awarded in 1970, and Plaketa Saveza muzičkih umjetnika Jugoslavije (Plaque of the

60 A list of works by Vida Matjan is provided in Ivana Antović, "Vida Matjan, veliki muzički pedagog i stvaralac druge polovine XX vijeka," Vaspitanje i obrazovanje: Časopis za pedagošku teoriju i praksu, no. 4 (2009): 155-169; Dabižinović, "Vida Matjan - 'duša svega',"74-75; Milošević, "Vida Matjan,"134-135.

61 The legacy of Vida Matjan is kept in the Historical Archives in Kotor (Državni arhiv Crne Gore, Istorijski arhiv Kotor, Muzička zbirka V, Vida Matjan (kompozicije, razno)).

62 Vida Matjan, Razgovor s povodom, radio interview, Radio Titograd, 1993, in Dabižinović, "Vida Matjan - 'duša svega',' 67.

63 For more on musical fairy tales by Vida Matjan, see Marković, "Influence of Slovenian Culture," 165. 
Association of Music Artists of Yugoslavia) on the occasion of twenty years of its existence (1950-1970). ${ }^{64}$ She was a member of Udruženje kompozitora Crne Gore (Association of Composers of Montenegro) from its founding in 1969, and a Lifetime Achievement award was presented to her in 1980. The most significant achievement at a Yugoslav level, and the crowning glory of her career was Orden zasluga za narod sa srebrnim zracima (Special Medal of Honour with Silver Rays) which she received from the president of the Republic of Yugoslavia in $1976 .{ }^{65}$

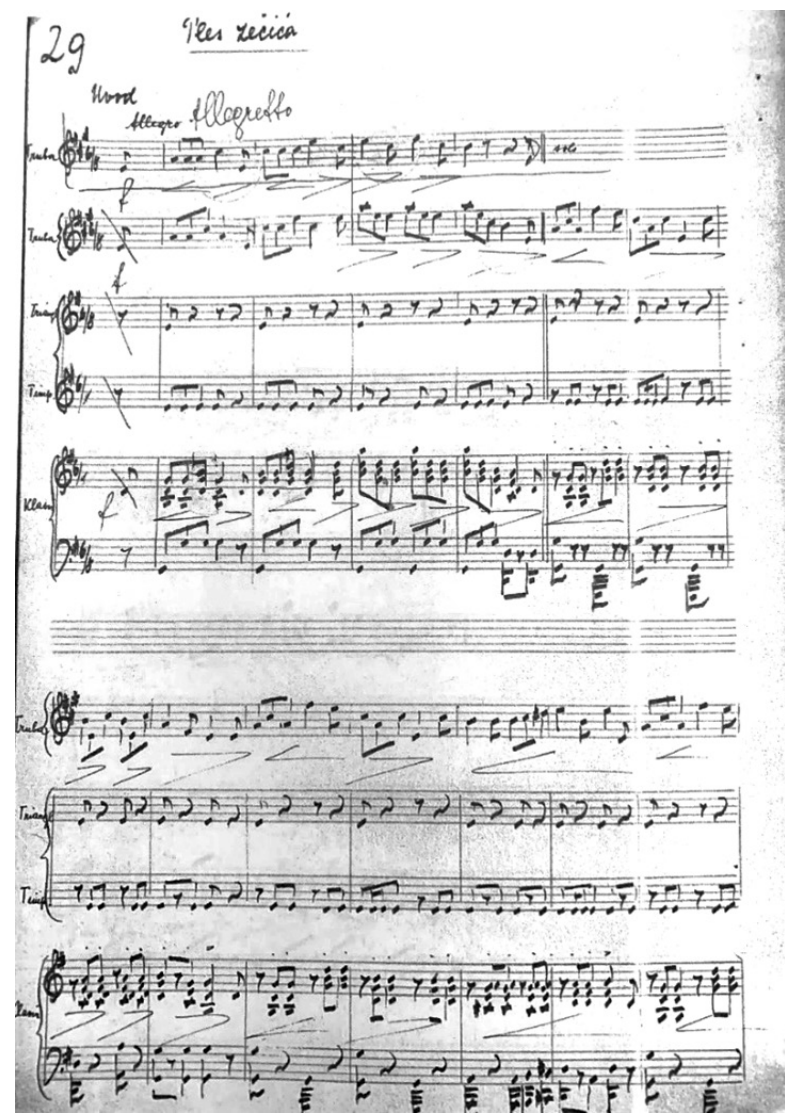

Figure 5: Vida Matjan: "Ples zečića" (Dance of the Rabbits") from the manuscript of the musical fairy tale The Sleepless Forest Night. ${ }^{66}$

64 Dabižinović, "Vida Matjan - 'duša svega'," 75.

65 "Predsjednik Republike odlikovao je Vidu Matjan [The President of the Republic honoured Vida Matjan]," Politika, Belgrade (May 15, 1976), taken from Antović, "Vida Matjan," 156.

66 Vida Matjan, Besana šumska noć (manuscript, Kotor, 1963), 29, Državni arhiv Crne Gore, Istorijski arhiv Kotor, Muzička zbirka V, Vida Matjan (kompozicije, razno), 1.1. 


\section{Vide Matjan's Approach to Initial Musical Education}

\section{The manuscript entitled $A$ Music Primer, authored by Vida Matjan and Miloš} Milošević, ${ }^{67}$ was created in 1962, and the final version of the manuscript from 1981 can be found in the Historical Archives in Kotor. It was the first methodical manual for initial music teaching that was written in Montenegro. The manuscript is a methodical manual for music teachers, intended for those working with children in the first grade of primary school and in the preparatory grade of music school, i.e., ages 6-7. It contains clear methodical instructions for the teacher, includes seventeen of the author's songs adapted to the needs of initial teaching, instructions for listening to music, work in the field of rhythm, and playing Orff percussion instruments.

Vida Matjan paid special attention to working with the youngest age-group in the preparatory class. Her approach was based on the creation of visual impressions through carved figures on a flannelgraph as a didactic tool and with certain musical examples. ${ }^{68}$ The flannelgraph itself is a $122 \mathrm{~cm}$ long and $67 \mathrm{~cm}$ wide hardboard, covered with white flannel or, as the authors say, "some other rough fabric." Given the fact that in the literature, the flannelgraph is not often mentioned as a didactic tool, it can be considered that Vida Matjan founded its use in the teaching of solfeggio in music schools. The scenery and figures are made of cardboard, and they are painted according to marked numbers, and according to the legend of the provided colours. On the back of the made figures, a piece of sticky paper is glued with which the figures can stand on the flannelgraph. The methodological path is based on the author's knowledge that painting and the visual experience are especially successful in helping to work with the youngest age-group. She designed drawings of figures and backdrops ${ }^{69}$ for each song intended for processing, since she also had an exceptional gift for artistic expression. The authors describe in detail for each song what the scenery looks like and how the figures are set. It is stated that the teacher in the simplest way presents the content of the verses that will be memorised and sung in class, setting up a figure or backdrop that is being talked about at that moment. The figures are arranged by numbers, as shown in the picture for each class, with the final appearance of the flannelgraph. In addition to its predominant role in the process of learning the text, the flannelgraph was also

67 Vida Matjan and Miloš Milošević, Muzička početnica (Kotor, 1981), Državni arhiv Crne Gore, Istorijski arhiv Kotor, Muzička zbirka V, Vida Matjan (kompozicije, razno), 13.1/2. For more information see: Vedrana Marković and Andrea Ćoso-Pamer, "Muzička početnica - tragom jednog rukopisa," in Zbornik XX Pedagoškog foruma scenskih umetnosti, ed. Milena Petrović (Beograd: Fakultet muzičke umetnosti, 2018), 21-32.

68 In music pedagogical practice, flannelgraph is not considered a common didactic tool in the teaching of solfeggio. Thanks to the pedagogical work of Vida Matjan, the flannelgraph can be included in the teaching aid that was used in the past in the teaching of solfeggio.

69 The original flannelgraph used by Vida Matjan is kept in the Historical Archive in Kotor. In a special box, there are interesting figures that she designed, with very vivid colours (Državni arhiv Crne Gore, Istorijski arhiv Kotor). 
used for graphical representation of the rhythmic flow, where the size of the symbol clearly indicates longer or shorter rhythmic values. ${ }^{70}$

The importance of Vida Matjan's work was recognised beyond the borders of Montenegro, as demonstrated in an article written by Stella Colaković in the Croatian journal Glazba i škola (Music and School):

\section{Professor $V$. Matjan, however, is not only a kind of innovator in music pedagogy, but also the author of an original music primer who, through visual impressions and adequate children's texts, introduces beginners to the complex world of music very easily and interestingly. ${ }^{71}$}

To our knowledge, Vida Matjan had no significant contact with her contemporary music pedagogues. The use of Orff instruments, creating arrangements, connecting music with movement, and involving students in the processes of performing works, can certainly be connected with the tradition of Slovenian music pedagogy, in which the influence of Orff's methodological concept and Dalcroze's Eurythmics is obvious.

Although she played a very important role in the development of the cultural scene in the Bay of Kotor, her pedagogical ideas and methodological approach were not recognised in the broader context of the development of music pedagogy in Montenegro, nor did they influence the formation of specific directions or the establishment of a method, based on her pedagogical principals.

\section{Conclusion}

The development of music education in Montenegro as supported by the active work of the Slovenian musicians Anton Pogačar and Vida Matjan has an upward trajectory to its development. Although they managed the first state music schools, they tried to contribute to the overall development of Montenegrin music culture with intensive activities that included conducting, working on didactic literature, and composing.

Anton Pogačar faced the professional challenge of running the first Njegoš State Music School touring Montenegro and looking for talented children to whom he was fully dedicated, giving them the necessary attention that they could not get at the boarding school from their parents and sharing with them the difficulties of the post-war years. The fact that many important musicians for Montenegro graduated from this school confirms the success of his mission.

Vida Matjan remains a person of particular note in Montenegrin music pedagogy. Having said that, her method of work, which was based on a multimodal

70 Representation of musical durations and movements of melodies with graphic symbols, before learning of musical notation, is a common methodological procedure in modern textbooks.

71 Stella Čolaković, Muzika i škola 3 (1966): 95, as cited in Antović, “Vida Matjan,” 160. 
and holistic approach, remains characteristic of herself, and future researchers will have the task of researching the methods she applied in music education. In this paper, we have pointed out only some aspects of that rich musical experience, through the presentation of her didactic work, Muzička početnica.

It is noteworthy that both Pogačar and Matjan showed significant interest in the musical folklore of Montenegro. Anton Pogačar incorporated it into his own compositions and wrote a specific score for the theatre production of The Mountain Wreath, which particularly marked out this achievement. Vida Matjan was deeply invested in the collecting of songs, dances, and customs of the Boka, which were collected in her ethnographic study Dances and Songs of Dobrota and $\check{S} k$ aljari. The majority of her works have been left as a bequest to the city of Kotor, in whose Archive her neatly arranged manuscripts are stored, waiting to be rediscovered by the musical public, most especially the children for whom she wrote the majority of her works.

This paper aimed to present these musicians as dedicated artists, pedagogues, and visionaries, both to the Slovenian music public and to those who want to grasp as fully as possible the permeations and influences of different cultures and identities on the development of music education in the second half of the twentieth century in the former Yugoslavia, as a shared cultural space.

\section{Bibliography}

“70 godina škole: Koncert 'Susret Generacija' povodom jubileja škole: Program." In J. U. umjetnička škola za muziku i balet 'VASA PAVIĆ' (5. 06. 2017). Accessed May 18, 2021. http://kicpodgorica.me/wp-content/uploads/2017/06/program-Koncert-Susret-generacija-5.pdf.

Antović, Ivana. "Vida Matjan veliki muzički pedagog i stvaralac druge polovine XX vijeka.” Vaspitanje i obrazovanje: Časopis za pedagošku teoriju i praksu, no. 4 (2009): 155-169.

“Bivši učenici: Julio Marić.” In Škola za osnovno muzičko obrazovanje Herceg Novi (2015). Accessed May 12, 2021, http://muzickahercegnovi.com/ page/12/.

Dabižinović, Ervina. "Vida Matjan - 'duša svega', uspješna Slovenka u Crnoj Gori.” Slovenika: Časopis za kulturu, nauku i obrazovanje, 4 (2018): 53-80. https://doi.org/10.18485/slovenika.2018.4.1.2.

Gajić, Milica. "Ivanović Aleksa.” In Srpski biografski rečnik. Vol. IV: I-Ka. Novi Sad: Matica Srpska, 2009. Accessed February 17, 2021. http://montenegrina.net/fokus/milica-gajic-biografije-ivanisevic-jovana-ivanovic-alekse-ijovovic-spiridona-spira/.

Ivanović, Cvjetko. "Muzika u Crnoj Gori nekad i sad.”In Udruženje kompozitora Crne Gore: 25 godina, edited by Marko Rogošić, 11-29. Podgorica: Udruženje kompozitora Crne Gore; Kulturno-prosvjetna zajednica Podgorice, 1996. 
Ivanović, Vesna. "O prošlosti / About the Past." In Montenegrin Symphony Orchestra: The First Decade 2007-2017, edited by Žarko Mirković and Jelena Jovanović-Nikolić, 51-53. Podgorica: Muzički centar Crne Gore, 2017.

Marinković, Sonja. "Muzička akademija na Cetinju: Pogled na osnovanje, razvoj i sadašnji rad najviše obrazovne institucije u Crnoj Gori.” In Muzičko školstwo u Crnoj Gori - dometi i perspektive, 144, no. 43, edited by Žarko Mirković, 83-94. Podgorica: CANU, 2018.

Marković, Vedrana. "Influence of Slovenian Culture and Music Pedagogy on the Development of Music Education in Montenegro through Work of Vida Matjan." Mostovi med formalnim in neformalnim glasbenim izobraževanjem - Glasbenopedagoški zbornik Akademije za glasbo v Ljubljani, 31, thematic issue (2019): 161-167.

Marković, Vedrana, and Andrea Ćoso-Pamer. "Muzička početnica - tragom jednog rukopisa." In Zbornik XX Pedagoškog foruma scenskih umetnosti, edited by Milena Petrović, 21-32. Beograd: Fakultet muzičke umetnosti, 2018.

Martinović Bogojević, Jelena. "Views of Elementary Music Education in Montenegro and Slovenia." Javno glasbeno šolstvo na Slovenskem: Pogledi ob 200-letnici - Glasbenopedagoški zbornik Akademije za glasbo v Ljubljani, 25, thematic issue (2016): 305-316.

Matjan, Vida, and Miloš Milošević. Besana šumska noć. Kotor, 1963. Državni arhiv Crne Gore, Istorijski arhiv Kotor, Muzička zbirka V, Vida Matjan (kompozicije, razno), 1.1.

Matjan, Vida. Igre i pjesme Dobrote i Škaljara: Etnomuzikološke studije. Titograd: Pobjeda, 1984.

Matjan, Vida, and Miloš Milošević. Muzička početnica. Kotor, 1981. Državni arhiv Crne Gore, Istorijski arhiv Kotor, Muzička zbirka V, Vida Matjan (kompozicije, razno), 13.1/2.

Miladinović Prica, Ivana. "Skladateljice v Črni gori: Zgodovina nekega razmerja." In Ženskost v glasbi skladateljic po 1918: Pogledi nekaterih manjših glasbenih kultur Evrope, edited by Leon Stefanija and Katarina Bogunović Hočevar, 73-90. Ljubljana: Oddelek za muzikologijo Filozofske fakultete Univerze v Ljubljani, 2018. https://doi.org/10.4312/9789610601388.

Milošević, Miloš. "Vida Matjan.” In Muzičke teme i portreti. Titograd: Crnogorska Akademija Nauka i Umjetnosti, 1983.

Milošević, Miloš. "Dionizije de Sarno San Đorđo (sa naročitim osvrtom na muzičko djelovanje u Kotoru (1886-1892)." In Muzičke teme i portreti. Titograd: Crnogorska Akademija Nauka i Umjetnosti, 1983.

"Muzičke škole." In Školska mreža. Accessed May 14, 2021. http://www. skolskamreza.edu.me/muzicke-skole/.

Pejović, Vesko. Srednja muzička škola na Cetinju, Konstantin Ivanović. Accessed March 1, 2021. http://www.cetinje-mojgrad.org/2010/08/srednjamuzicka-skola-na-cetinju-konstantin-ivanovic/. 
Pogačar, Anton. "Iz života i rada Srednje muzičke škole Njegoš." In Deset godina Srednje muzičke škole Njegoš Cetinje - Kotor 1946/47-1956/57: Almanah, edited by Pero Šegota, 59-99. Kotor: Srednja muzička škola, 1957.

Pogačar, Anton. Motiv iz Crne Gore. Cetinje: Narodna knjiga, 1949.

Pogačar, Anton. Muzički priručnik za nastavu pjevanja u srednjim školama. Cetinje: Narodna knjiga, 1948.

Pogačar, Anton. Pionir na harmoniko: 100 vaj za začetnike; Narodne in partizanske pesmi za klavirsko harmoniko. [S. 1.]: [s. n.], 1946.

Pogačar, Anton, Venček melodij (Ouvertura): Izoperete Povodni možpo istoimenski Prešernovi baladi; Priredba za klavir. [S. 1.]: [s. n.], 1946.

Pogačar, Anton. Zvuci iz Crne Gore: Crnogorskoj omladini. Cetinje: Narodna knjiga, 1947.

Radojević, Milovan. "Prve dvije decenije Crnogorskog narodnog pozorišta." Matica (2013): 339-426.

Radulović Vulić, Manja. "In memoriam: Rudolf Zakrajšek; Crnogorski Slovenac." Pobjeda, [n. d.]. Private archive of Zoran Zakrajšek. Accessed March 1,2021.

Radulović Vulić, Manja. "Muzička kultura u Crnoj Gori.”In Crna Gora, edited by Olga Perović, Sreten Perović, Stanislav Vujošević, and Čedo Vuković. Titograd: Organizacioni odbor dana Crne Gore, 1981. Accessed February 15, 2021. http://www.montenegrina.net/pages/pages1/muzika/muzicka_ kultura_u_cg_m_radulovic_vulic.htm.

Rakijaš, Branko. "Muzičko školstvo u Jugoslaviji." In Muzička enciklopedija. Vol. II, edited by Krešimir Kovačević, 653-654. Zagreb: Jugoslavenski leksikografski zavod, 1974.

Rogošić, Marko, ed. Udruženje kompozitora Crne Gore: 25 godina. Podgorica: Udruženje kompozitora Crne Gore, Kulturno-prosvjetna zajednica Podgorica, 1996.

Rogošić, Marko. "Osnivanje prvih muzičkih udruženja u Crnoj Gori 19471957.” In Udruženje kompozitora Crne Gore: 25 godina, edited by Marko Rogošić, 30-33. Podgorica: Udruženje kompozitora Crne Gore, Kulturnoprosvjetna zajednica Podgorice, 1996.

Simonuti, Tripo. "Spavao sam sa violinom." Interview by Slavko Trošelj. Politika, April 22, 2007. http:/www.politika.rs/sr/clanak/1966/.

Vlahović, Vukašin. "Anton Pogačar." Muzički glasnik, 4. Podgorica: Udruženje kompozitora Crne Gore, 1997. Accessed February 20, 2021. http://www. montenegrina.net/pages/pages1/muzika/anton_pogacar.htm.

Zadnik, Katarina."Primary Music School Education in Slovenia and Montenegro." Muzikološkizbornik55, no.1(2019). https://doi.org/10.4312/mz.55.1.195-210.

Wiggins, Jackie. “Creative Process as Meaningful Music Teaching.” In Creativity and Music Education, edited by Timothy Sullivan and Lee Willingham, 78-88. Toronto: Canadian Music Educators' Association, 2002. 


\section{POVZETEK}

\section{Prispevek Antona Pogačarja in Vide Matjan k črnogorski glasbeni kulturi}

Članek prikazuje vlogo in pomen dveh slovenskih glasbenikov, ki sta se po drugi svetovni vojni ustalila v Črni gori in s svojo dolgoletno dejavnostjo ključno prispevala k razvoju tamkajšnje glasbene kulture. To sta Anton Pogačar (1913-1995) in Vida Matjan (1896-1993). Posebna pozornost je namenjena vplivu, ki sta ga imela na razvoj glasbenega izobraževanja med ustanavljanjem prvih državnih glasbenih šol v Črni gori. Dejavna sta bila kot glasbena pedagoga, dirigenta in skladatelja, pa tudi kot ustanovitelja in člana glasbenih združenj. Pogovori $\mathrm{z}$ njunimi nekdanjimi učenci in sodelavci so prispevali $\mathrm{k}$ osvetlitvi njunih osebnosti kot tudi njunih pedagoških procesov. Glasbene pravljice Vide Matjan, ki so bile namenjene otrokom in po katerih je bila znana ter zanje nagrajena $\mathrm{v}$ nekdanji Jugoslaviji, niso bile niti objavljene niti uprizorjene, kar bi lahko predstavljalo enega od pristopov k nadaljnjemu raziskovanju njenega bogatega ustvarjalnega opusa. Vido Matjan lahko imamo zaradi njenega multimodalnega pristopa in umetniškega sinkretizma - od dramskega uprizarjanja glasbe in ustvarjanja koreografij do uporabe otrokom ljubih besedil - za vizionarko in inovatorko $\mathrm{v}$ glasbeni pedagogiki. Ob tem raziskava posebno pozornost posveča opisu Glasbenega priročnika (1962), prvega metodološkega učbenika za solfeggio, ki ga je napisala z Milošem Miloševićem. V učbeniku, ki še zmeraj ni bil objavljen in ki ga hranijo v Zgodovinskem arhivu Kotor, Vida Matjan sinkretično in celovito pristopa k začetnemu glasbenemu izobraževanju otrok, pri čemer je kot še posebej inovativen pripomoček za poučevanje solfeggia uporabila flanelograf. Članek obravnava tudi črnogorsko folkloro, predvsem z vidika Vide Matjan, ki je popisovala ljudske pesmi in plese, in Antona Pogačarja, ki jo je uspešno vključil v svoje kompozicije. Namen članka je združiti doslej znane podatke $z$ izsledki novih raziskav, širši glasbeni in strokovni javnosti predstaviti pomen obeh glasbenikov in spodbuditi nadaljnje muzikološke raziskave.

\section{ABOUT THE AUTHORS}

JELENA MARTINOVIĆ BOGOJEVIĆ (jelena.bo@ucg.ac.me) is an Associate Professor at the Academy of Music of the University of Montenegro. She obtained her PhD degree at the Academy of Music, University of Ljubljana, in the field of music pedagogy. She is the author of scientific and professional papers and the editor and author of two monographs in the field of music pedagogy and piano teaching methods. She is a member of the Committee for Music at the Montenegrin Academy of Sciences and Arts (CANU) and cofounder of the International Symposium on Music Pedagogy (SIMPED) which is held in Cetinje (Montenegro). She is also the national coordinator for Montenegro for the European Association for Music in Schools (EAS).

VEDRANA MARKOVIĆ (vedranam@ucg.ac.me) graduated from the Faculty of Music in Belgrade, gaining her $\mathrm{PhD}$ in 2015. She has been employed at the Academy of Music in Cetinje as an Assistant Professor since 2009. She participates actively in scientific gatherings in Montenegro and the wider region. She has published one monograph, exercises for solfeggio 
teaching, book sets for the first, second and third grades of music school, and around thirty other studies. Her particular area of interest includes the musical education of children with visual impairment, as well as the implementation of examples from Montenegrin music heritage in music education, especially in solfeggio teaching. She has also published papers in the field of musicology concerning the historical development of music pedagogy in Montenegro.

\section{O AVTORICAH}

JELENAMARTINOVIĆ BOGOJEVIĆ (jelena.bo@ucg.ac.me) je izredna profesorica na Akademiji za glasbo Univerze v Črni gori. Doktorirala je na Akademiji za glasbo Univerze v Ljubljani s področja glasbene pedagogike. Je avtorica več znanstvenih in strokovnih člankov in urednica ter avtorica dveh monografij o glasbeni pedagogiki in metodah poučevanja klavirja. Je članica Odbora za glasbo na Črnogorski akademiji znanosti in umetnosti (CANU) in soustanoviteljica Mednarodnega simpozija glasbene pedagogike (SIMPED), ki poteka v Cetinju (Črna gora). Jelena Martinović Bogojević je nacionalna koordinatorica za Črno goro pri Evropskem združenju za glasbo v šolah (EAS).

VEDRANA MARKOVIĆ (vedranam@ucg.ac.me) je diplomirala na Fakulteti za glasbo v Beogradu, kjer je leta 2015 tudi doktorirala. Od leta 2009 je kot docentka zaposlena na Akademiji za glasbo v Cetinju. Aktivno se udeležuje srečanj znanstvenikov v Črni gori in šrše v regiji. Doslej je izdala monografijo, vaje za poučevanje solfeggia, vrsto učbenikov za prvi, drugi in tretji razred glasbene šole in približno trideset drugih raziskav. Posveča se predvsem glasbenemu izobraževanju otrok $z$ okvarami vida kot tudi implementaciji primerov črnogorske glasbene dediščine pri glasbenem izobraževanju, še posebej pri poučevanju solfeggia. Objavila je tudi več člankov s področja muzikologije, in sicer na temo zgodovinskega razvoja glasbene pedagogike v Črni gori. 